\title{
Correction to: Image-guided selection of Gd@C-dots as sensitizers to improve radiotherapy of non-small cell lung cancer
}

Xiaofen $\mathrm{Ma}^{1,2+}$, Chaebin Lee ${ }^{3 \dagger}$, Tao Zhang ${ }^{2 \dagger}$, Jinghua Cai ${ }^{2}$, Hui Wang ${ }^{2}$, Fangchao Jiang ${ }^{3}$, Zhanhong Wu ${ }^{2}$, Jin Xie ${ }^{3^{*}}$, Guihua Jiang ${ }^{1^{*}}$ and Zibo Li ${ }^{2^{*}}$

\section{Correction to: J Nanobiotechnol (2021) 19:284} https://doi.org/10.1186/s12951-021-01018-9

Following publication of the original article [1] the authors have identified an error in Fig. 8 and 9. The correct version of figures are shown below.

The authors apologise for this error.

The original article can be found online at https://doi.org/10.1186/s12951021-01018-9.

\footnotetext{
*Correspondence: jinxie@uga.edu; jiangguihua1970@163.com; ziboli@med.unc.edu

'Xiaofen $\mathrm{Ma}$, Chaebin Lee and Tao Zhang contributed equally to the research

1 Department of Nuclear Medicine, Guangdong Second Provincial General Hospital, 466 Xingang Middle Road, Haizhu District, 510317 Guangzhou City, Guangdong Province, People's Republic of China

${ }^{2}$ Department of Radiology, Biomedical Research Imaging Center, and Lineberger Comprehensive Cancer Center, University of North Carolina at Chapel Hill, 125 Mason Farm Road, Chapel Hill, NC 27599, USA

${ }^{3}$ Department of Chemistry, University of Georgia, 140 Cedar Street, Athens, GA 30602, USA
} original author(s) and the source, provide a link to the Creative Commons licence, and indicate if changes were made. The images or other third party material in this article are included in the article's Creative Commons licence, unless indicated otherwise in a credit line to the material. If material is not included in the article's Creative Commons licence and your intended use is not permitted by statutory regulation or exceeds the permitted use, you will need to obtain permission directly from the copyright holder. To view a copy of this licence, visit http://creativecommons.org/licenses/by/4.0/. The Creative Commons Public Domain Dedication waiver (http://creativeco mmons.org/publicdomain/zero/1.0/) applies to the data made available in this article, unless otherwise stated in a credit line to the data. 

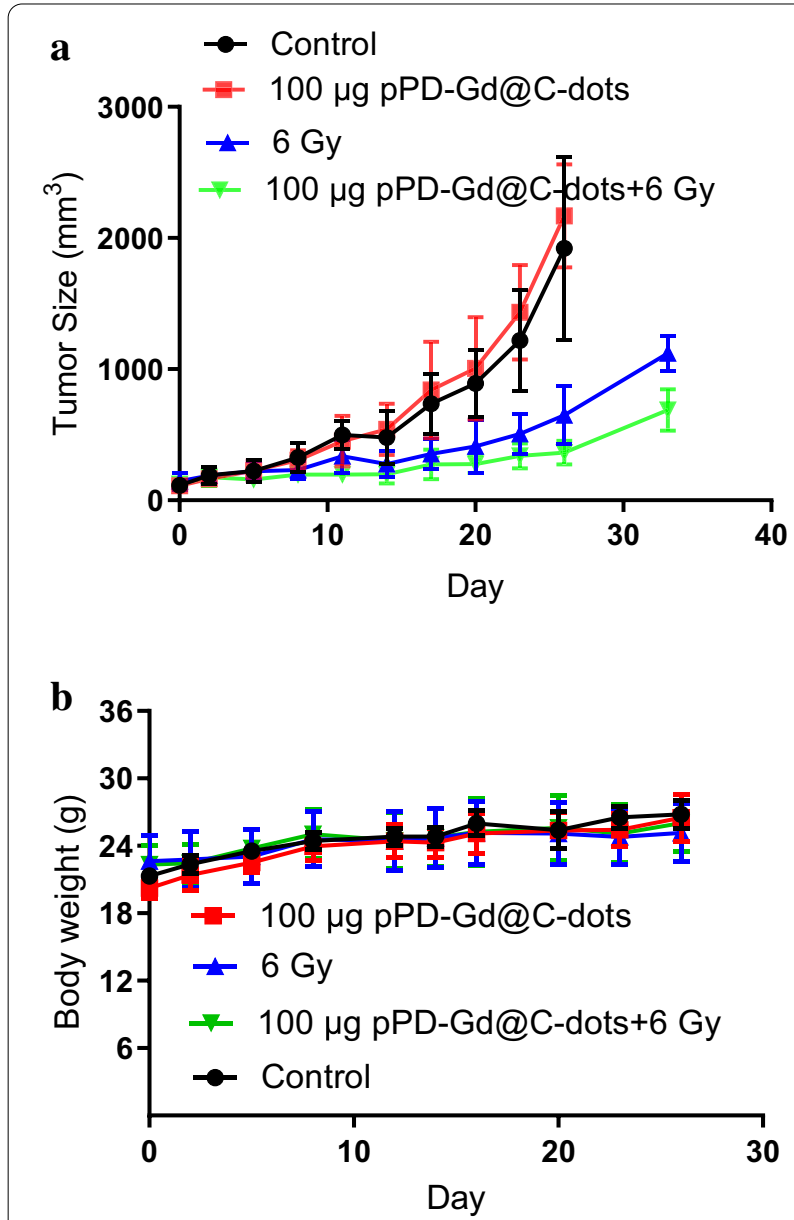

Fig. 8 X-Ray radiotherapy studies on H1299 tumor models. Animals received one session of treatment on Day 0 . a Tumor growth curves. Tumors were measured by monitoring tumor diameter changes at different time points. Compared to X-Ray irradiation alone and pPD-Gd@C-dots injection only, significant tumor suppression was found with animals injected with pPD-Gd@C-dots and X-ray irradiation. b Body weight curves
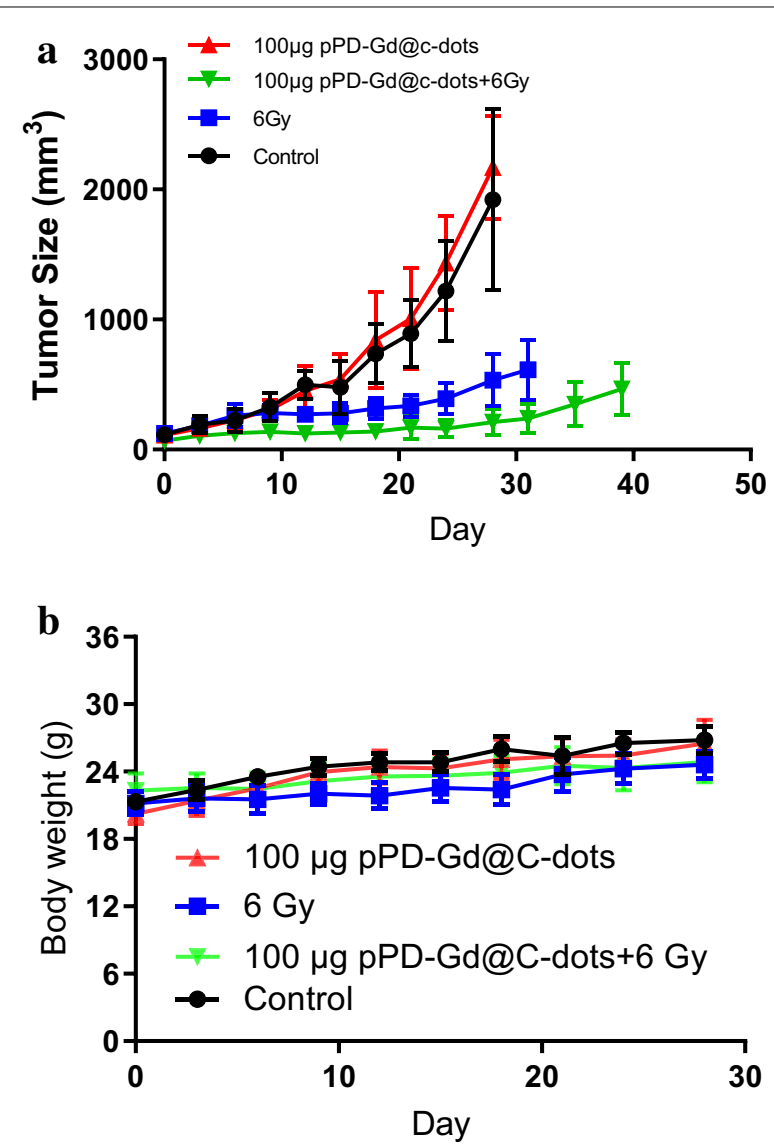

Fig. 9 X-Ray radiotherapy studies on H1299 tumor models. Animals received two doses of treatment on Days 0 and Day 3. a Tumor growth curves. Tumors were measured by monitoring tumor dimension changes at different time points. Compared to X-Ray irradiation alone and pPD-Gd@C-dots injection only, significant tumor suppression was found with animals treated with pPD-Gd@C-dots plus irradiation. b Body weight curves

Published online: 03 January 2022

\section{Reference}

1. Ma X, Lee C, Zhang T, Cai J, Wang H, Jiang F, Wu Z, Xie J, Jiang G, Li Z.

Image-guided selection of Gd@C-dots as sensitizers to improve radiotherapy of non-small cell lung cancer. J Nanobiotechnol. 2021;19:284. https://doi.org/10.1186/s12951-021-01018-9.

\section{Publisher's Note}

Springer Nature remains neutral with regard to jurisdictional claims in published maps and institutional affiliations. 